\title{
Experimental evaluation of a constructive system for earthquake resisting masonry enclosure walls
}

\author{
L. Silva, G. Vasconcelos, P. Lourenço \& F. Akhoundi \\ Department of Civil Engineering, University of Minho, Portugal
}

\begin{abstract}
University of Minho is a partner of the INSYSME research project (Innovative Systems for earthquake resistant masonry enclosures in RC buildings), funded by the European Commission. The main aims of this project are to study new systems for masonry infill walls, which combine simplicity with low cost, and to propose recommendations and calculation procedures for their design to seismic actions, filling an existing gap in current regulations. At University of Minho a new construction system for masonry enclosures was developed, being composed of a new commercial unit and vertical steel reinforcement placed in ceramic brick frogs, connected to top and bottom beams. In this paper, the experimental work developed at the University of Minho for validation of the solution proposed for masonry infills is presented and discussed. The experimental validation process of the solution for the masonry enclosure walls was based on in-plane and out-of-plane static cyclic tests. The tests were carried in four specimens built at reduced scale (1:1.5). In order to assess the in-plane behaviour, two specimens have been tested. The first test was done, in a specimen with masonry infill, until maximum drift. In the second test, only reinforcement concrete frame was tested, to access the contribution of masonry infill. For out-of-plane direction two specimens were tested one without reinforcement, and other with reinforcement. The out-of-plane test was carried using an airbag system. In this case only positive direction was considered. In-plane and out-of-plane tests were performed under displacement control according to a load pattern defined based on the FEMA 461 recommendations.
\end{abstract}

\section{INTRODUCTION}

Masonry walls are a common solution for enclosures walls in many countries in southern and central Europe, mainly in Reinforced Concrete (RC) buildings, leading to the need of production of thousands of masonry units annually (Pompeu dos Santos 2007). In the last 50 years, several studies (Jorquera 1964; Fiorato et al. 1970) have been conducted to understand the influence of the masonry infill walls in RC structure, and the seismic behaviour of these infill walls. According to several authors, the masonry infill walls contribute significantly to the performance of buildings in terms of interior quality, and have a positive influence in the lateral resistance, in the stiffness and in the energy dissipation in RC frames (Vintzileou \& Tassios 1989). However, there are still problems in the behaviour of these walls especially when they are subjected to seismic action (Lourenço et al. 2010), because although they are considered non-structural, they contribute to withstand the seismic action.

The recent earthquakes in Lefkada in 2003 (Karakostas et al. 2005), L'Aquila in 2009 (Braga et al. 2011), Van in 2011 and Emilia Romagna in 2012 (Magenes et al. 2012), among others, showed that masonry infills walls can affect the global and local behaviour of the RC structures. These earthquakes allowed to observe that contemporary structures in reinforced concrete have a reasonable ability to withstand seismic loads, given that were designed for this purpose according to the current design codes (NP EN 1998-1 2010). Sometimes it is possible to observe some kind of damage like soft-story or short column associated with the improper use of masonry infill walls. In case of masonry infill walls, since they are considered non-structural walls, usually it is not made any safety check to the seismic actions. Eurocode 8 (NP EN 1998-1 2010), is silent in this case and only present a simplified procedure for the calculation of the out-of-plane action, but does not provide design recommendations. On the other hand, this code considers that verification of the safety of non-structural elements is guaranteed if the relative displacements between floors are limited. However, states that appropriate measures should be taken to avoid brittle failure and premature disintegration of infill walls. Seismic events cited above allowed to observe significant damage occurring in this type of walls. The most common pathologies are the separation between masonry panels and structural elements, diagonal cracking, and out-of-plane partial or total collapse. This type of damage can put in danger human life and is also associated with considerable economic losses (Al-Chaar et al. 2002; Bertero \& Brokken 1983), 
as happened in the Loma Prieta earthquake (1989) and Northridge (1994), where the costs associated with non-structural damage amounted to 30 million US dollars (Vicente et al. 2010).

Following the problems identified above, the INSYSME European project (606229) has as the main objective the development of innovative systems for masonry enclosures walls that resist better to seismic action. These solutions are designed to be used in new construction, using traditional materials. This article focuses on the presentation of a new constructive system for masonry infill walls in Portugal in order to improve the seismic performance of masonry infill walls.

\section{CONSTRUCTION SYSTEM}

\subsection{Description of the system}

The construction system proposed at University of Minho uses masonry units made of clay with vertical holes and a tongue and groove interlocking in vertical direction. The unit dimensions are $250 \times 250 \times 100 \mathrm{~mm}$ in height, length and thickness respectively, see Figure 1.

These masonry units have grooves at the surface that make possible the addition of vertical reinforcement bars. In this system it was decided to use steel bars with a diameters of $6 \mathrm{~mm}$.

With this solution, it is intended that the masonry infill walls are single-leaf enclosures that take advantage of the possible energy dissipation potentialities at the interlocking vertical joint, due to sliding between masonry units. The masonry units are placed aligned with the length in the vertical direction, leading to the definition of continuous vertical joints. The out-of-plane behaviour is intended to be improved by adding steel rebars in the face of masonry units, being connected at top and bottom reinforced concrete beams with a chemical anchor (Hilti HIT-HY 200-A). This solution uses vertical dry joints and mortared bed joints, where a general purpose mortar (pre-mixed mortar M10 class) is applied. The masonry infill

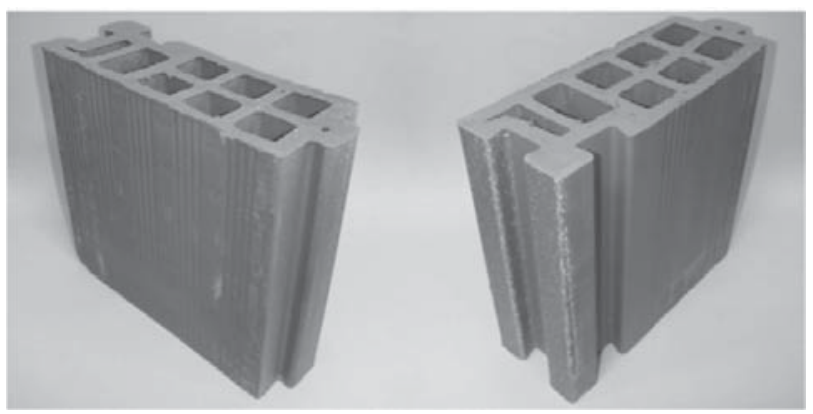

Figure 1. Uniko masonry brick unit. is connected to the concrete frame rigidly through general purpose mortar that is also used for the laying the masonry units.

\subsection{Construction process}

The construction process of this system proposed in University of Minho is similar to normal construction process of current masonry infill walls, see Figure 3.

In this system, it is intended that the system allows the sliding between bricks in vertical joints, which implies the consideration of a change on the common masonry bond. Besides, the addition of vertical reinforcement implies that previous works need to be done. Therefore, the construction process begins with the drilling of holes to attach the vertical reinforcement at the bottom and upper reinforced concrete beams. Subsequently, the first layer of mortar is placed on the bottom beam

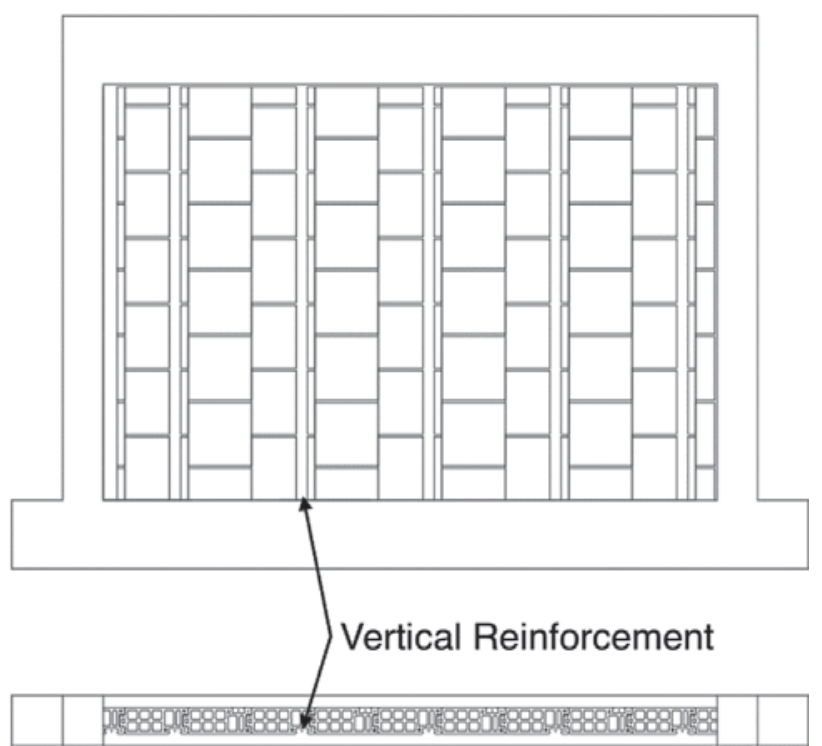

Figure 2. Final aspect of masonry infill panel.



Figure 3. Construction of masonry wall. 
along the line of the wall construction. After this, the bricks are placed along the construction line, ensuring that they are properly seated and aligned. The application of the vertical reinforcement is done after the conclusion of the masonry wall, being anchored to the reinforcement concrete beams with the chemical anchoring. The connection of the masonry infill to the concrete columns is made through the application of mortar, similar to the one used for the bed joints, at each row of units. In the final stage, when the construction of the wall is complete, a layer of mortar between the brick wall and the upper concrete beam must be applied to ensure adequate connection between masonry and concrete top beam.

\section{EXPERIMENTAL PROGRAM}

\subsection{Description of the specimen}

The reinforced concrete frame considered in the present study is representative of the actual building practice in Portugal. The definition of the typical $\mathrm{RC}$ frame was based on an extensive work carried out on a database of buildings from the building stock from different cities in Portugal (Furtado et al. 2014). Due to the laboratory limitations, it was decided to test reduced scale specimens $(1: 1,5)$, see Figures 4 and 5.

For this, Cauchy's Similitude Law was considered. Therefore, the geometry of the frame was reduced to 1,5 times and the reinforcing scheme was updated so that the relation between resisting bending moments and shear resisting forces could be well correlated between full and 1:1,5 scale frames. The geometry and reinforcement scheme adopted for the 1:1,5 scale RC frame are shown in Figures 4 and 5.

The masonry infill panel was built with $250 \times 250 \times 100 \mathrm{~mm}$ uniko bricks with vertical perforation. The steel used for the construction of RC frame and for reinforcement of masonry infill panel was a A400 NR, with a yielding tensile strength of $400 \mathrm{MPa}$. In case of concrete, a C25/30 class was used for the construction of the RC frame. A M10 mortar was adopted for the laying of the masonry units. The thickness of the horizontal joints was assumed to be $0,5 \mathrm{~cm}$. The compressive strength of units and mortar was obtained for the bricks (parallel and perpendicular to the holes) based on (EN 772-1 2011) (EN 1015-11 1999) respectively. The results of the average compressive and flexural strength are represented in Table 1.

\subsection{Test Setup and instrumentation}

The test setup for the in-plane loading of the infilled frames is shown in Figure 6. The infilled frame was placed on two separated steel beams of HEA300 that were firmly attached to the strong floor to avoid their sliding on the floor. The sliding of the infilled frame was prevented by bolting an L-shape steel profile to each side of the steel beam and its uplifting was also prevented by bolting two

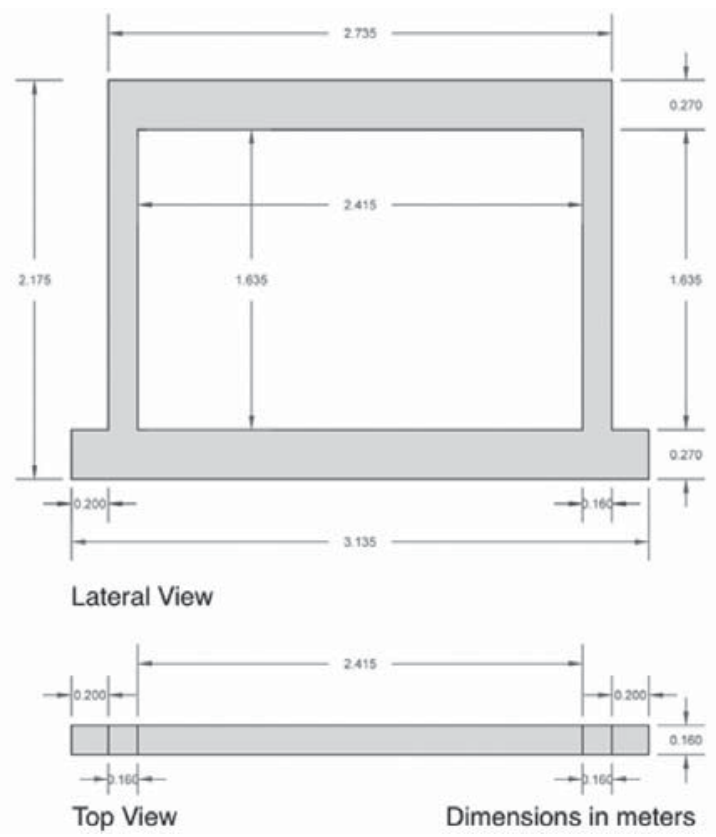

Figure 4. Geometric scheme of RC frame.

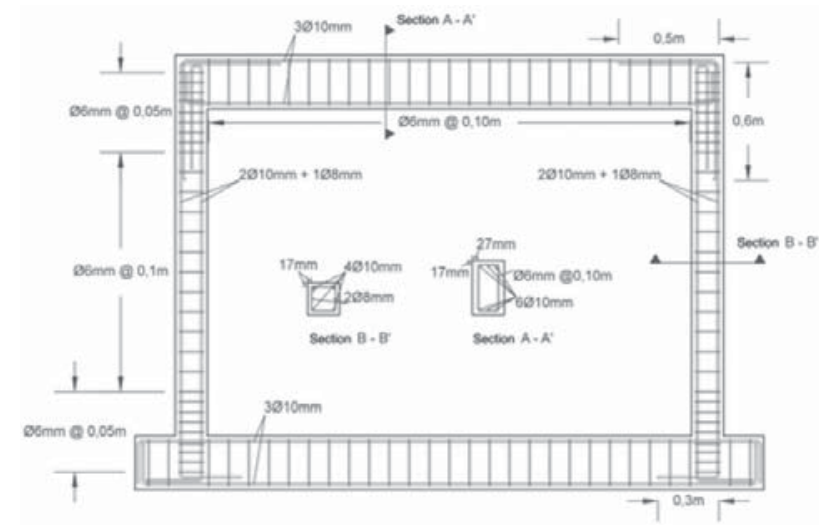

Figure 5. Reinforcement scheme used in RC frame.

Table 1. Compressive and flexural strength of the bricks and mortar used in the masonry infill wall.

\begin{tabular}{ll} 
Masonry Units (MPa) & \\
\hline Compressive Strength Parallel to the holes & 13.62 \\
$\begin{array}{l}\text { Compressive Strength Perpendicular to } \\
\text { the holes }\end{array}$ & 0.66 \\
\hline Mortar (MPa) & \\
\hline Compressive Strength & 10.39 \\
Flexural Strength & 3.29
\end{tabular}


rectangular-shape steel profiles to the steel beams. The rectangular shape steel profile was made by welding two UNP140. The out-of-plane movement of the enclosure frame was restrained by putting the L-shaped steel frame on each side of the upper beam. Those profiles were bolted to the upper steel beams. Three rollers were placed on upper L-shaped profiles to minimize or even completely eliminate the friction between them and the upper reinforced concrete beam during in-plane loading.

Two vertical jacks were mounted on the top of the columns to apply the vertical load of $200 \mathrm{KN}$, corresponding to $30 \%$ of the column's axial force capacity. Those jacks are pinned to the lower steel beams by means of four vertical rods of $\Phi 16 \mathrm{~mm}$. A hydraulic actuator with capacity of $250 \mathrm{kN}$ was attached to the reaction wall to apply the in-plane cyclic loading to the specimen. A steel plate of $400 \times 300 \times 30 \mathrm{~mm}$ was connected to the hydraulic actuator that applies the load in positive direction from right to left direction.

This steel plate was connected to other one with the same dimensions by $2 \Phi 50 \mathrm{~mm}$ steel rods to enable to pull the specimen in the negative direction. These steel plates enable also to have a uniform distribution of the horizontal load in the cross-section of the upper beam.

An instrumentation scheme to measure the inplane most relevant displacements during the inplane testing is shown in Figure 7.

Eighteen linear variable differential transformer (LVDT) devices were used to record the displacement in selected points. From them, two LVDTs were mounted on the masonry infill to measure the deformation of the infill (L1 and L2), and eight LVDTs were used to measure the relative displacement of the infill with respect to its surrounding frame (L3, L4, L5, L6, L7, L8, L9 and L10). The LVDTs L11 and L12 were placed to measure the sliding and uplifting of the infilled frame with respect to the steel profile. Four LVDTs L13, L14, L15 and L16 measure the sliding and uplifting of the steel profiles with respect to the strong floor. LVDTs L17 and L18 measure the horizontal displacement of the upper reinforced concrete frame.

The test setup for out-of-plane loading is shown in Figure 8. The infilled frame was supported on the same steel profiles used for the in-plane testing setup. The out-of-plane restriction at the top and bottom RC beams was strengthened so that outof-plane displacements at the boundaries could be prevented. For this, four steel rods connected to a steel device, connected in turn to the horizontal steel profiles were added at each side of the top RC beam, see Figure 8.

The out-of-plane loading is applied by means of an airbag that is connected to an external supporting frame. Four rollers were mounted in the

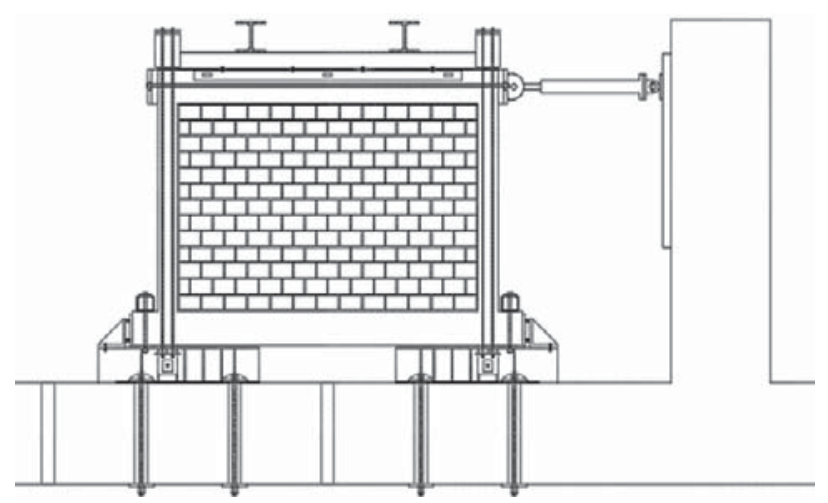

Figure 6. In-Plane test setup for cyclic loading.

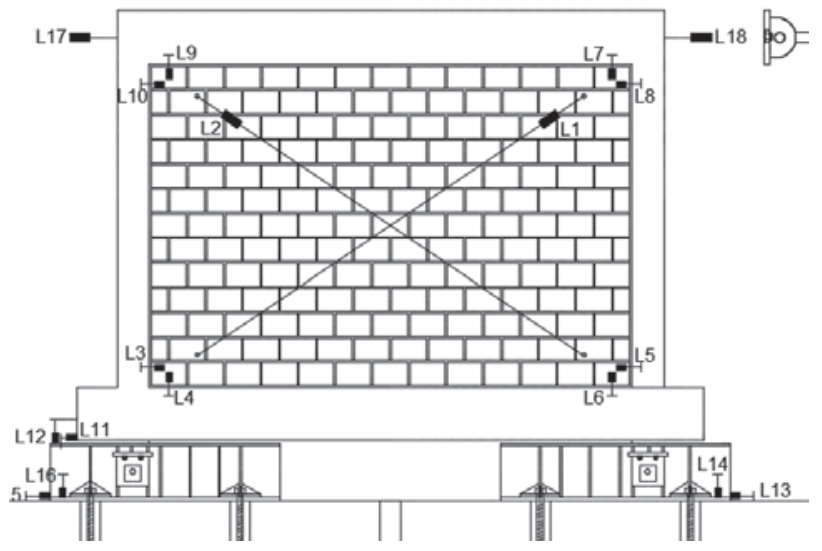

Figure 7. In-Plane instrumentation plan.



Figure 8. Lateral view of out-of-plane test setup.

bottom part of the supporting frame enabling its moving along the direction of applied load without friction. The supporting frame was also kept in touch with four load cells to measure the load that is applied to the infill walls through the airbag, see Figure 8 , where a detail about the system of the four load cells is shown (section A-A). The supporting frame, to which the load cells are attached, was firmly connected to the strong floor and to the lateral reaction wall, which prevented completely 
any uplifting and sliding of the out-of-plane reaction structure.

The instrumentation plan of the out-of-plane testing is shown in Figure 9.

A total number of fifteen LVDTs were placed on the specimen to monitor its deformation while the out-of-plane load is applied. From them, nine LVDTs record the displacement history of the infill panel during loading (LVDT L1 to L9). Four LVDTs measure the relative displacement between infill and its surrounding frame (L10 to L13) and two LVDTs measure the out-of-plane movement of the upper and bottom reinforced concrete beam (L14 and L15).

\subsection{Loading pattern for in-plane and out-of-plane tests}

The in-plane testing was performed under displacement control by imposing different predefined levels of displacement by the hydraulic actuator, see Table 2. The loading pattern was computed in accordance with FEMA 461 (FEMA461 2007). It is composed of sixteen different sinusoidal steps that starts from displacement of $0.5 \mathrm{~mm}(0.026 \%$ drift) up to the lateral displacement of $75 \mathrm{~mm}$, corresponding to a lateral drift of $3.94 \%$. Each step was repeated two times except for the first step that repeated six times.

The amplitude $a_{i+1}$ of step $i+1$ is 1.4 times of the amplitude $a_{i}$ of step $i$. Table 2 shows the drifts, the displacements and the number of repetitions for each cycle adopted for in-plane testing.

In the case of loading pattern for out-of-plane, a quasi-static cyclic testing (one cyclic direction), the same approach was used, being the test conducted also in displacement control (Akhoundi et al. 2015). The first amplitude was repeated for six times and the others repeated two times to

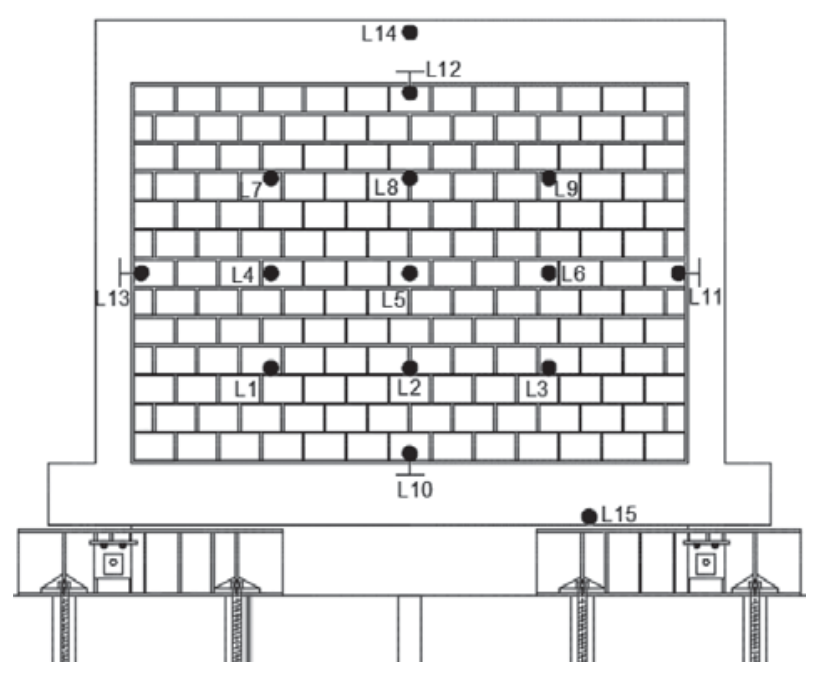

Figure 9. Out-of-plane instrumentation plan.
Table 2. In-plane loading pattern.

\begin{tabular}{llll}
\hline Cycle & $\begin{array}{l}\text { Drift } \\
(\%)\end{array}$ & $\begin{array}{l}\text { Displacement } \\
(\mathrm{mm})\end{array}$ & $\begin{array}{l}\text { Number of } \\
\text { repetitions }\end{array}$ \\
\hline 1 & 0.026 & 0.50 & 6 \\
2 & 0.037 & 0.70 & 2 \\
3 & 0.051 & 0.98 & 2 \\
4 & 0.072 & 1.37 & 2 \\
5 & 0.100 & 1.92 & 2 \\
6 & 0.141 & 2.69 & 2 \\
7 & 0.198 & 3.76 & 2 \\
8 & 0.277 & 5.27 & 2 \\
9 & 0.387 & 7.38 & 2 \\
10 & 0.542 & 10.33 & 2 \\
11 & 0.759 & 14.46 & 2 \\
12 & 1.063 & 20.25 & 2 \\
13 & 1.488 & 28.35 & 2 \\
14 & 2.083 & 39.69 & 2 \\
15 & 2.917 & 55.56 & 2 \\
16 & 3.937 & 75.00 & \\
\hline
\end{tabular}

investigate the strength degradation of the specimen at each displacement increment. The point selected to control the test was the midpoint of the masonry infill wall (mid height and at mid length). The loading was performed in one direction to monitor the deformation of the infill, propagation of the cracks and performance of the interfaces between infill and reinforced concrete frame. In out-of-plane load pattern for the cycle sixteen the displacement used was $77.78 \mathrm{~mm}$, corresponding to a lateral drift of $4.08 \%$.

The experimental campaign is composed of two specimens under in-plane loading (a bare frame, and a RC frame with a reinforced masonry infill wall-US03). Additionally, two specimens were tested to out-of-plane loading, namely one specimen without reinforcement (US01) and another specimen (US02) with a reinforcement scheme shown in Figure 2.

\section{TEST RESULTS}

\subsection{In-Plane behaviour}

The in-plane lateral force-displacement diagram obtained for the Uniko system (US03) during inplane loading is shown in Figure 10.

As mentioned before, positive direction is considered to be the direction where the hydraulic actuator pushes the specimen, whereas the negative direction is the direction that the actuator pulls the specimen by two plates that connected with two thick rods.

This diagram presents some differences in the positive and negative directions. The specimen reached maximum load of $94.54 \mathrm{kN}(+40 \%$ than 


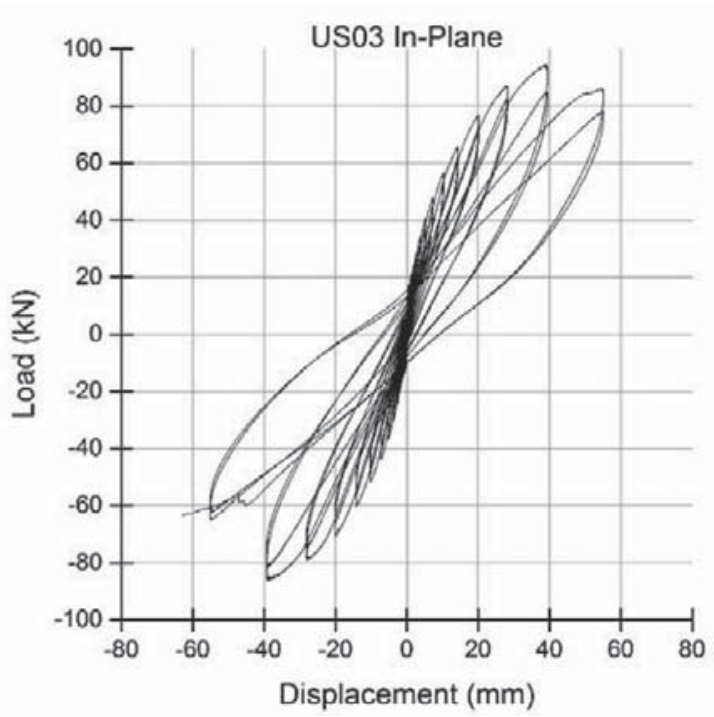

Figure 10. In-plane force-displacement diagram of Uniko system.

bare frame) at displacement of $39.69 \mathrm{~mm}$ corresponding to lateral drift of $2.08 \%$. After the peak load the lateral force decreased until a residual strength around $80 \mathrm{kN}$ for $55.56 \mathrm{~mm}$ displacement $(2.92 \%$ drift $)$. On the other hand, for the negative direction, the specimen reached its peak load of $-86.22 \mathrm{kN}$ at displacement of $39.69 \mathrm{~mm}$ (lateral drift of $2.08 \%$ ). Lateral force was gradually decreased and reached a force around $65 \mathrm{kN}$ at the displacement of $55.56 \mathrm{~mm}(2.92 \%$ drift $)$.

As mentioned above, one of the in-plane test was carried out only in the bare frame to access the influence that masonry infill wall in the global cyclic behaviour. By comparing the force-displacement diagrams for RC bare frame and RC infilled frame, it is observed that an increase on the lateral strength was observed in case of the RC infilled frame, see Figure 11. The bare frame achieved a maximum load of $67.60 \mathrm{kN}$ at displacement of $53 \mathrm{~mm}$ corresponding to a lateral drift of $2.78 \%$. After the peak load was reached, a reduction of lateral load of about $17 \%$ was recorded at a displacement of about $75 \mathrm{~mm}(3.93 \%$ drift). For the negative direction, the specimen presents a similar behaviour. The maximum load for this direction was $-54.38 \mathrm{kN}$ at displacement of $46.98 \mathrm{~mm}$ $(2.47 \%$ drift). For the last cycle of $75 \mathrm{~mm}$ the lateral force was decreased for a value around $52 \mathrm{kN}$.

Comparing these two in-plane tests, it is possible to conclude that the use of masonry infill wall means the increase on the lateral resistance of approximately $40 \%$. However, and as expected, the stiffness of infilled RC frame is higher than stiffness exhibited by the bare frame. The drift for maximum load is lower in the infilled frame, being of $2.08 \%$, while in bare frame the drift corresponding to the maximum lateral resistance was $2.78 \%$.

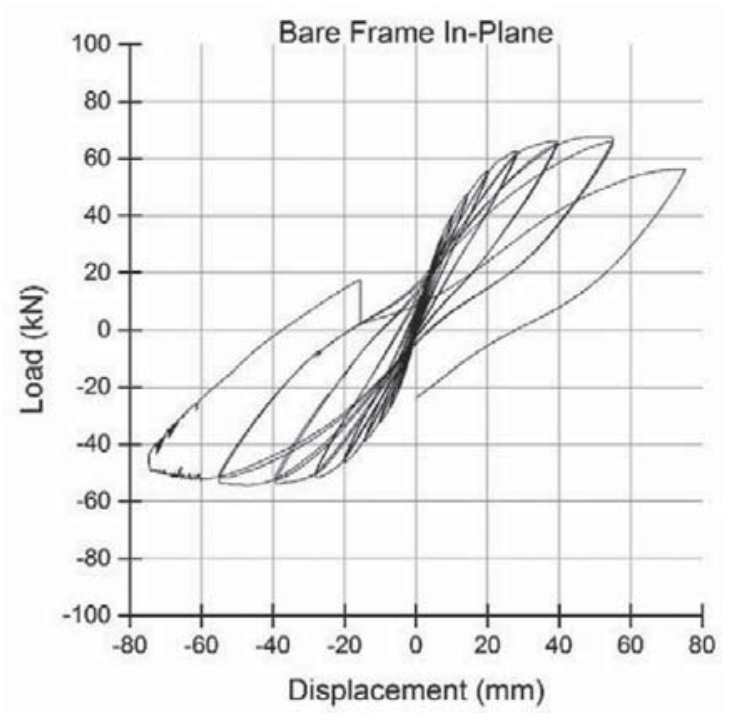

Figure 11. In-Plane force-displacement diagram of Uniko system bare frame.

The cracking pattern of infilled wall start at cycle 7, for a displacement of $5.23 \mathrm{~mm}$ corresponding to a lateral drift of $0.27 \%$. At this level of deformation, the cracking initiate at the interface between top beam and masonry infill. In next cycles, cracks start to appear at the bottom part of the infill and their opening increases for increasing imposed lateral displacement. The central part of infill does not present any crack, probably due to some sliding that occurs in continuous vertical joints. At the end of the test the damage is concentrated in the top and bottom part of infill, according to what can be seen in Figure 12.

For the bare frame the cracks start at cycle 8, for a drift of $0.34 \%$ (7.32 $\mathrm{mm}$ displacement), at bottom part of columns. For increasing displacements, the cracks concentrates in the top intersections between the columns and beams.

\subsection{Out-of-plane behaviour}

For the out-of-plane direction, two tests have been done, as mentioned above, only in positive direction. One of them without reinforcement (US01) and the other one with reinforcement (US02). In the case of masonry wall without reinforcement, the force-displacement diagram obtained for outof-plane loading is shown in Figure 13.

After an initial linear behaviour, the response become nonlinear before the maximum load is reached. The system reached maximum load of $52.50 \mathrm{kN}$ at a displacement of $21.93 \mathrm{~mm}$ corresponding to lateral drift of $1.15 \%$. After the peak load, the behaviour presents same softening, and the lateral force decreased until a resistance around $28 \mathrm{kN}$ for $55.56 \mathrm{~mm}$ displacement $(2.92 \%$ drift $)$, before collapse. 




Figure 12. Crack pattern of US03, at final of test.

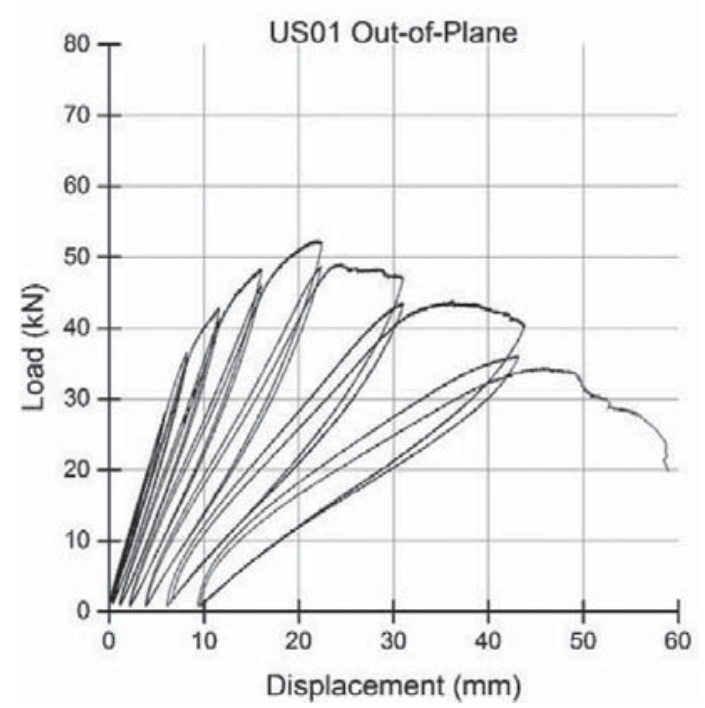

Figure 13. Out-of-Plane force-displacement diagram of Uniko system without reinforcement.

In terms of crack pattern for this wall the first cracks start to appear in central part of wall in cycle $8,0.27 \%$ drift $(5.27 \mathrm{~mm})$. After this in next cycles until the final of test the cracks open from the central part to the corners of the wall. It is possible to observe the development of an arch mechanism in vertical direction.

From Figure 14 it is possible to observe the wall at the final stage of, in which a horizontal stepped crack develops at mid height of the walls as the results of the development of the arching resisting mechanism in the vertical direction. Additionally, it is seen that vertical cracks and crushing of the units occur close to the interface between infill and columns, which should be associated to the stress concentration due to the arching developed in horizontal direction.

The force-displacement diagram for the out-ofplane test in the RC frame with reinforced masonry infill walls is shown in Figure 15.



Figure 14. Crack pattern of US01, at final of test.

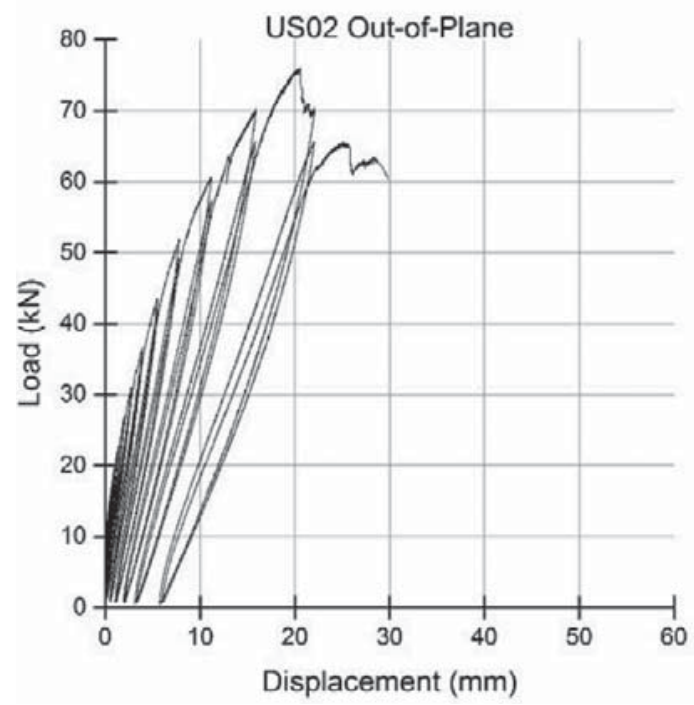

Figure 15. Out-of-Plane force-displacement diagram of Uniko system with reinforcement.

In this case the response of the composite structure is in stiffer than the RC frame with masonry walls without reinforcement. The maximum load achieved is also higher than the previous one, reaching a lateral resistance of $76 \mathrm{kN}$ at displacement of $20.59 \mathrm{~mm}$ corresponding to lateral drift of $1.08 \%$, representing an increase of about $45 \%$. Despite the ability to reach higher loads, the behaviour after the peak load is quite fragile and have lower capacity to deform after the peak load. The system shows some softening, but the wall collapsed in the next cycle for a lateral force around $60 \mathrm{kN}$ and for an out-of-plane lateral displacement of $29.85 \mathrm{~mm}(1.57 \%$ drift $)$.

The crack pattern for this wall is similar to previous wall the first cracks start to appear in central part of wall in cycle 7, 0.19\% drift $(3.76 \mathrm{~mm})$. In final cycles of test some vertical cracks occur in right part of wall due to the crushing of masonry units. In this test was possible to observe the development of arch mechanism in vertical direction. 


\section{CONCLUSIONS}

This paper presents and discuss same results obtained for in-plane and out-of-plane cyclic testing carried out on a new solution defined to improve masonry infilled RC frames. This system was developed by University of Minho in the scope of a European project INSYSME.

In the in-plane direction the masonry infill achieves higher resistance in about $40 \%$ than the bare frame. The global behaviour of hysteric curves was similar, both presenting softening after peak load, but in case of strength degradation the infilled frame presents more degradation in the second cycle corresponding to the same displacement level. In case of stiffness, the infilled frame presented also higher stiffness than bare frame as expected, and the stiffness degradation is lower.

For the out-of-plane direction, it was possible to apply a uniform load using an airbag, which is considered to me more representative of the outof-plane lateral induced load by earthquakes. The resisting mechanism in both tests was an arching mechanism more evident in vertical direction. In both specimens it was possible to catch the postpeak behaviour showing same softening. The strength degradation on the cyclic repetitions was evident in both specimens. The addition of reinforcement in the masonry infill resulted in the increase of the maximum lateral resistance and stiffness. The increase in the lateral resistance was about $45 \%$, but the post-peak behaviour changed. In this case the RC frame with reinforced masonry infilled wall become more fragile. The collapse of the masonry infill occurred for a lateral drift of $2.92 \%$ in case of inexistence of reinforcement and for a lateral drift of $1.57 \%$ in the wall with vertical reinforcement.

This fragile behaviour could be associated with the connection between the reinforcement and concrete beams. Since the reinforcement in anchored in beams, any lateral deformation in reinforcement bars are allowed. This restriction leads to local stress concentration in the neighbourhood of the reinforcement leading to the crushing in masonry units and the failure of infill wall.

\section{ACKNOWLEDGMENTS}

The authors gratefully acknowledge the funding from the European Union's Seventh Framework Programme for research, technological development and demonstration under grant agreement No 606229, which support this work. This work was also supported by FCT (Portuguese Foundation for Science and Technology), within ISISE, project UID/ECI/04029/2013.

\section{REFERENCES}

Akhoundi, F. et al., 2015. In-plane and out-of-plane experimental characterization of RC masonry infilled frames. In J.F.S. Gomes \& S.A. Meguid, eds. Proceedings of the 6th International Conference on Mechanics and Materials in Design. Ponta Delgada, pp. 427-440.

Al-Chaar, G., Issa, M. \& Sweeney, S., 2002. Behavior of Masonry-Infilled Nonductile Reinforced Concrete Frames. Journal of Structural Engineering, 128(August), pp.1055-1063.

Bertero, V. \& Brokken, S., 1983. Infills in seismic resistant building. Journal of Structural Engineering, 109(6), pp.1337-1361.

Braga, F. et al., 2011. Performance of non-structural elements in RC buildings during the L'Aquila, 2009 earthquake. Bulletin of Earthquake Engineering, 9(1), pp.307-324.

CEN, 1999. EN 1015-11:1999 Methods of test for mortar for masonry; Part 11: Determination of flexural and compressive strength of hardened mortar.

CEN, 2011. EN 772-1:2011 Methods of test for masonry units - Part 1: Determination of compressive strength.

CT 115, 2010. NP EN 1998-1: Eurocódigo 8 - Projecto de Estruturas para resistência aos sismos. Parte 1: Regras gerais, acções sísmicas e regras para edifícios. 1 .

FEMA461, 2007. Interim Testing Protocols for Determining the Seismic Performance Characteristics of Structural and Nonstructural Components. (June).

Fiorato, A.E., Sozen, M. a \& Gamble, W.L., 1970. An Investigation of the Interaction of Reinforced Concrete Frames with Masonry Filler Walls, Available at: http://oai.dtic.mil/oai/oai?verb = getRecord\&metadat aPrefix $=$ html\&identifier $=$ AD0719267.

Furtado, A. et al., 2014. Characterization of structural characteristics of Portuguese RC buildings with masonry infill walls stock. In 9th International Masonry Conference. pp. 1-12. Available at: http:// www.9imc.civil.uminho.pt/.

Jorquera, L.G., 1964. Estudio experimental sobre la resistencia de muros de albãnileria sometidos a cargas horizontales. Revista del IDIEM, 3.

Karakostas, C. et al., 2005. Seismic response of structures and infrastructure facilities during the Lefkada, Greece earthquake of 14/8/2003. Engineering Structures, 27(2), pp.213-227.

Lourenço, P.B. et al., 2010. Vertically perforated clay brick masonry for loadbearing and non-loadbearing masonry walls. Construction and Building Materials, 24(11), pp.2317-2330.

Magenes, G. et al., 2012. Preliminary damage survey to masonry structures after the May 2012 Emilia earthquakes v.1, Available at: http://www.eqclearinghouse. org/2012-05-20-italy-it.

Pompeu dos Santos, S., 2007. Enclosure masonry walls systems worldwide CIB Publication, ed., Taylor and Francis.

Vicente, R. et al., 2010. Masonry enclosure walls: lessons learnt from the recent Abruzzo Earthquake. In 14th European Conference of Earthquake Egnineering.

Vintzileou, E. \& Tassios, T.P., 1989. Seismic behaviour and design of infilled R.C. frames. European Earthquake Engineering, 3(1), pp.22-28. 